\title{
CASE STUDY INFORMATION REFLECTING FARMER USE OF PAWERA RED CLOVER IN NORTHERN NORTHLAND
}

GAVIN USSHER

Farm Advisor, MAF, Kaitaia

\section{Abstract}

Low summer production in Northern Northland can be largely overcome by the use of 'Grasslands Pawera' red clover. Daily dry matter production of $100+\mathrm{kg} / \mathrm{ha}$ /day over the period late October to early March, have been recorded over two years. Yearly production of $22,000 \mathrm{~kg}$ DM/ha in the first year, and 17,500 to 21,000 in the second year, have been recorded from pure stands of Pawera. This growth is of very high quality occurring at a time when growth and stands of Pawera. This growth is of very high quality occurring at a time when growth and
quality of existing Rye or Kikuyu based pastures, are low. Potential problems from the use of Pawera are discussed.

Keywords: Pawera red clover, quality, Northland, problems.

\section{INTRODUCTION}

Animal production in Northern Northland from November to March is limited by low to very low pasture production. A summer producing species, ideally offering high quality feed, is required. Red clovers (Trifolium pratense L.), 'Grasslands Turoa' and 'Grasslands Hamua', have produced up to $14,000 \mathrm{~kg}$ DM/ha/year sown as a pure stand in the Kaitaia area (Taylor 1979).

'Grasslands Pawera' tetraploid red clover has shown to be highly productive in other summer drought prone areas (Hay and Ryan 1983).

This paper reports farmer use of Pawera red clover in Northern Northland.

\section{METHO D}

Seed sales were obtained from the Stock and Station firms based in Kaitaia. plus individual farmers.

Dry matter production measurements were taken pre and post grazing in the first year. In the second year cage areas were measured by cutting $0.10 \mathrm{~m}^{2}$ quadrats with hand shears to ground level. Cages were moved onto pre trimmed areas equating to post grazing residual levels.

\section{RESULTS}

Interest in the use of Pawera red clover by Northern Northland farmers has greatly increased over the last two years (Table 1), and is generally used as part of a permanent pasture mix, although a few farmers have sown it on its own as a temporary special purpose pasture (Table 2).

\section{Case Farm: Mr A Cole, Kaitaia}

A pure Pawera pasture sown in the autumn of 1983 produced 22,000kg DM/ha in both its first and second years. In the autumn of 1985 this pure Pawera pasture, because of a declining Pawera population in January. March 1985. was drilled with Ellett ryegrass (Lolium perenne L.) at $15 \mathrm{~kg} / \mathrm{ha}$ and Pitau white clover (T.repens L.) at $3 \mathrm{~kg} / \mathrm{ha}$.

Figure 1 illustrates the increase in pasture growth obtained from the 2 year old Pawera, and 1 year old Pawera and Matua prairie grass (Bromus wildenowii) pasture compared to the pasture growth from the old pasture on the balance of the farm, being a Kikuyu (Pennisetum clandestinum) dominant pasture.

Pawera . Matua prairie grass mixtures sown in the autumn of 1984 , yeilded $14,000 \mathrm{~kg}$ DM/ha during its first summer (November 1984 March 1985), 80\% being 
TABLE 1: Sales of Pawera Red Clover Seed (Kg) and the Number of Farmers Purchasing.

\begin{tabular}{lcccc}
\hline & 1982 & 1983 & 1984 & 1985 \\
\hline $\begin{array}{l}\text { Pawera kg } \\
\text { (Equivalent Bare Seed Weight) }\end{array}$ & 50 & 480 & 1588 & $1970^{\prime}$ \\
$\begin{array}{l}\text { Number of Farmers Purchasing } \\
\text { Pawera Seed }\end{array}$ & 2 & $y$ & 20 & 44 \\
\hline
\end{tabular}

Sales of Pawera were restricted in 1985 because of seed being unavailable for periods.

TABLE 2: Mode of Use of Pawera Red Clover • Kaitaia 1985

$\%$ of Total Pawera Seed Sales

\begin{tabular}{lr}
\hline Sown as Pure Pawera Stand & $4 \%$ \\
Sown with grasses other than Perennial Ryegrass & $8 \%$
\end{tabular}

Sown with Perennial Ryegrasses

1 Wana Cocksfoot, Matua Prairie

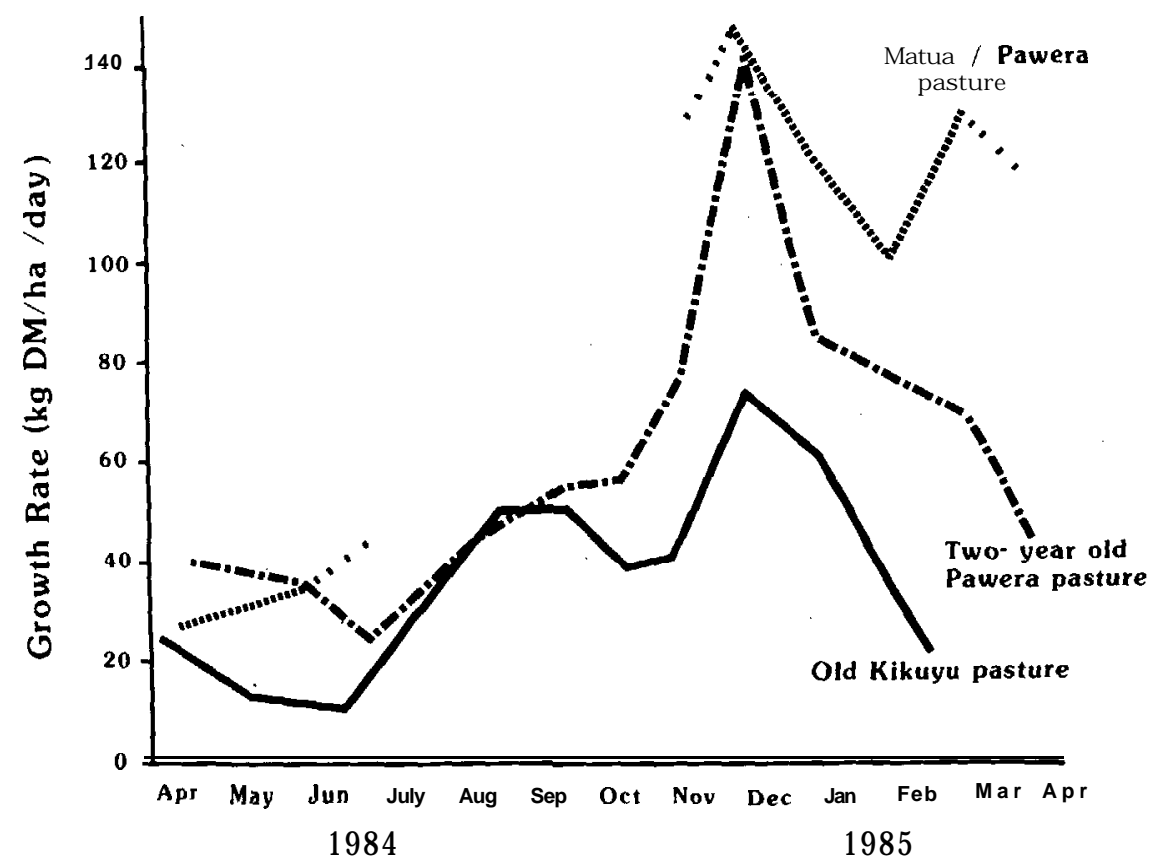

FIGURE 1: Growth Rates of Different Pasture Species in 1984-1985. 
Pawera, which exceeded the 12 month production of the Kikuyu based pastures of $12,200 \mathrm{~kg} / \mathrm{ha}$.

From January 251985 to April 25 the cows grazing the Pawera - Matua prairie pastures produced $210 \mathrm{~kg}$ of milkfat $/$ ha compared to $78 \mathrm{~kg}$ of milkfat $/$ ha from the old Kikuyu pastures. The extra $132 \mathrm{~kg}$ milkfat/ha produced by the Pawera base, returned $\$ 520 /$ ha, easily covering the establishment cost of $\$ 325 / \mathrm{ha}$.

\section{Case Farm: Mr D Hoult, Kaitaia}

Total area 69 ha, home farm 62 ha, runoff 7 ha.

Following very low pasture and animal production in the drought summer of 1982/1983, in the autumn of 198359 ha (85\% of the farm) were undersown with Ellett ryegrass (14 kg/ha), Pitau white clover $(2 \mathrm{~kg} / \mathrm{ha})$ and Pawera red clover $(2 \mathrm{~kg} / \mathrm{ha})$ and another 3 ha, ex-forage crops, were regrassed with a heavier rate of the same mix.

In the autumn of 198440 ha were undersown with the same species as in 1983. Another 5 ha were regrassed following a blanket herbicide spray and cultivation.

In 19857 ha were regrassed following a blanket spray and direct drill, using Ellett ryegrass (12 kg/ha), Wana cocksfoot $(4 \mathrm{~kg} / \mathrm{ha})$, Pitau white clover $(3 \mathrm{~kg} / \mathrm{ha})$ and Pawera red clover $(5 \mathrm{~kg} / \mathrm{ha})$.

TABLE 3: Dairy Production from the Hoult Farm, Kaitaia.

\begin{tabular}{lccc}
\hline & \multicolumn{3}{c}{ Year } \\
& $\mathbf{1 9 8 2 / 1 9 8 3}$ & $\mathbf{1 9 8 3 / 1 9 8 4}$ & $\mathbf{1 9 8 4 / 1 9 8 5}$ \\
\hline Total Milkfat (kg) & 10,000 & 19,000 & 21,200 \\
Milkfat/Hectare (kg) & 162 & 307 & 343 \\
Cows Milked & 110 & 130 & 150 \\
Increase/Year Milkfat (\%) & & +90 & +11 \\
Mangonui County Increase/Year (\%) & & +31 & +1 \\
\hline
\end{tabular}

\section{DISCUSSION}

Pawera has the ability to quickly establish following cultivation or direct drilling. The author has measured its tap root at $15 \mathrm{~cm}$ at 60 days post plant, and at $50 \mathrm{~cm}$ at 9 months post autumn planting.

Farmer experience has shown that to obtain maximum plant numbers Pawera should be established either from cultivation or from a blanket herbicide spray and direct drill (Ussher, unpublished).

Northern Northland farmers have found that establishment of a high Pawera population (greater than 30 plants/square metre) is very difficult following under or oversowinginto existing pasture. D. Hoult covered the same 35 ha with undersowingin 1983 and 1984. The 1984 undersowing was considered necessary to further increase the Pawera population. Compared to the Pawera population in the 5 ha that were regrased following a blanket spray, this repeat oversowing into the existing pasture was only partially successful. This lack of total success determined that in 1985,7 ha were regrassed following a blanket herbicide spray, and no undersowing into existing pastures. In its establishment phase competition against Pawera by the established pasture species must be eliminated.

The one factor having the largest impact on the production increases on Mr D Hoults farm, has been the introduction of the "new" pasture species: Of the species used in 1983 and 1984 Pawera red clover has given the most dramatic increase in pasture production, both yield and quality.

Pawera shows limited growth during the winter in most regions of New Zealand. In the Kaitaia region, with its relatively mild winters, an average of 2 frost days per year, Pawera shows considerable growth. Growth rates of $25 \mathrm{~kg} \mathrm{DM} / \mathrm{ha} /$ day have been 
recorded in July on heavy clay. Visual observation would suggest higher growth rates on drier soil types with their high soil temperatures during the winter.

Farmers in the Kaitaia region have been obtaining very high yeilds from Pawera. Possibly more importantly in the long term is the high nitrogen fixation by the Pawera which will be considerably higher than that from the struggling clovers that it replaced.

Improvement in feed quality obtained over the first two and hopefully three summers from Pawera are very large. It appears that the Pawera population declines in the third and fourth summers to the point that the pasture is no longer Pawera dominant, but there are still a considerable number of Pawera plants present.

The growth of Pawera increases rapidly in late October, remaining very high from November to January inclusive. This at a time when farmers are experiencing dropping milkfat production, low lamb growth rates. Pawera has the ability to produce significant quantities of very high quality feed at this critical time.

It is very important that Pawera dominant pastures be rotationally grazed at infrequent intervals so it can express its maximum growth potential (Hay and Ryan) 1983). Mr A Cole's 2 year old Pawera grew at an average of $116 \mathrm{~kg} \mathrm{DM} /$ ha/day from 26 November 1984 to 22 March 1985. One of the factors involved in this high growth rate was the 30-35 day rotation through that period.

This author's recommendation to farmers is that a minimum of a 30 day spell between grazing is required. Under very dry soil conditions this spell should be 40 days. For maximum persistance of Pawera this spelling is critical, especially if grazing residuals are below $1500 \mathrm{~kg}$ of $\mathrm{DM} / \mathrm{ha}$.

\section{Problems}

Bloat control of some form, is essential for dairy cows. Care will be needed with young beef cattle but bloat control should not be required. Farmers have not lost beef cattle while grazing Pawera dominant pastures.

The lowered fertility problem with breeding ewes reported by Shackell and Kelly (1984), is not seen as an obstacle for Northland sheep and beef farmers, who commonly have sheep to cattle ratios of 50:50. Farmers have sufficient number of stock other than breeding ewes, available to graze Pawera based pastures.

One problem some farmers have experienced, which has been noted in the research literature (Campbell et al. 1983, Campbell and Kumelius 1984), is the occasional instance of very poor germination of Pawera. With the high cost of Pawera seed, even the faint possibility of anything less than a $70 \%$ germination is unacceptable.

Avoidance of pugging is essential as Pawera will not persist under conditions of medium to severe pugging.

Poorly drained soil types have allowed root-knot nematode (Meloidogyne hapla) to shorten the life of Pawera plants to two years. This problem has been significant on two Kaitaia farms.

\section{CONCLUSION}

The low pasture production over the typical Northland summer can be alleviated in terms of both yield and quality by the use of Pawera red clover. Farmers are obtaining very large pasture and animal production increases through the increasing use of Pawera.

\section{Acknowledgements}

To those farmers in the Kaitaia region who have purchased Pawera red clover, specifically Messrs N Hunt, L Crewther, R Williams, A Cole, D Hoult, S Buckingham.

\section{References}

Hay, R.J.M., Ryan, D.J 1983, Proc, N.Z. Grasșld. Ass. 44: 91-97.

Campbell. B D.. Cosgrove, G.P., Harris, W. 1983, Ibid: 156-163

Campbell, B.D., Kunelius, H.T., 1984, N.Z. J. exp. Agric. 12; $71-81$

Shackell, G.H., Kelly, R.W. 1984, Ibid:113-117.

Taylor, A.O., Hunt, B.J., Hart, N.D., Walker, A., Guest, J., Harris, H., 1979, Technical Report No 7, Plant Physiology Dept, DSIR. 'Testing of Forage Crops on Northland Dairy Farms'. 